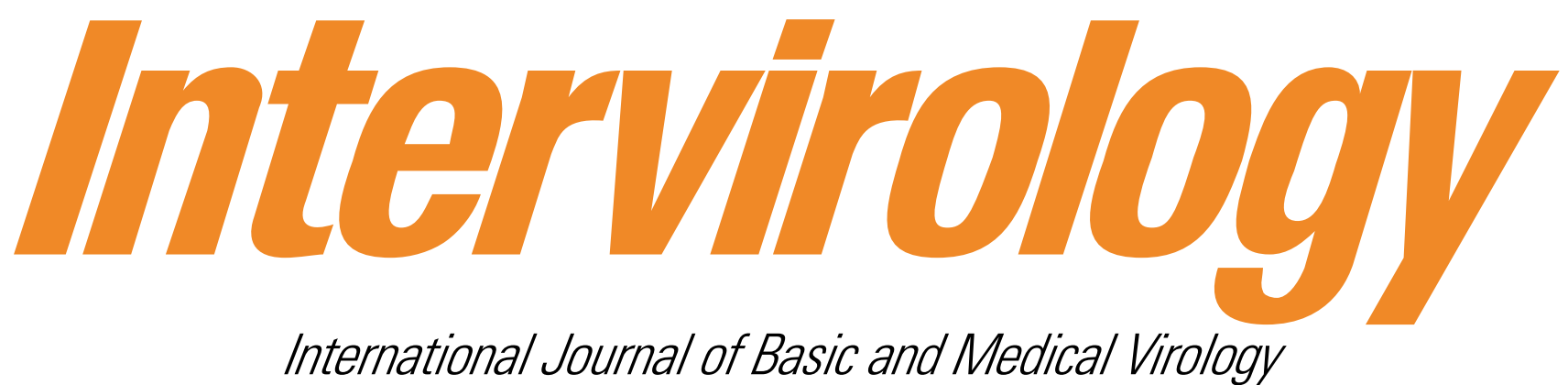

Review

321 Reclassification of Giant Viruses Composing a Fourth Domain of Life in the New Order Megavirales

Colson, P.; de Lamballerie, X.; Fournous, G.; Raoult, D. (Marseille)

\section{Original Papers}

333 Characterization of Infections of Human Leukocytes by Non-Polio Enteroviruses

Hwang, J.Y.; Jun, E.J.; Seo, I.; Won, M.; Ahn, J.; Kim, Y.K.; Lee, H. (Seoul)

342 Human Cytomegalovirus Glycoprotein B Genotypes in Chinese Hematopoietic Stem Cell Transplant Recipients

Xia, C.; Zhao, X.; Sun, Y.; Zhang, Z. (Beijing)

349 Generation and Biological Properties of a Recombinant Dodecahedron Containing the Short Fiber Protein of the Human Adenovirus 41 Siqueira-Silva, J. (São Paulo); Fenel, D.; Gout, E. (Grenoble); Yeda, F.P.; Marinheiro, J.C. (São Paulo); Barrella, K.M. (El Paso, Tex.); Silva, M.L. (São Paulo); Schoehn, G. (Grenoble); Harsi, C.M. (São Paulo); Fender, P. (Grenoble)

356 Adaptation of Genotype 3 Hepatitis E Virus in Eastern China and Inverse Correlation with Genotype 4 Hepatitis E Virus

Si, F.; Yang, Q. (Nanjing); Zhu, Y.; Dong, S.; Yu, R.; Shen, S.; Li, Z. (Shanghai)

365 Role of Water Fleas (Daphnia magna) in the Accumulation of Avian Influenza Viruses from the Surrounding Water Abbas, M.D.; Nazir, J.; Stumpf, P.; Marschang, R.E. (Stuttgart)
372 Epstein-Barr Virus Genotypes and Strains in Central Nervous System Demyelinating Disease and Epstein-Barr Virus-Related Illnesses in Australia Lay, M.-L.J. (Westmead, N.S.W.); Lucas, R.M. (Canberra, A.C.T.); Toi, C.; Ratnamohan, M. (Westmead, N.S.W.); Ponsonby, A.-L. (Parkville, Vic.); Dwyer, D.E. (Westmead, N.S.W.); The Ausimmune Investigator Group

Case Report

380 Simultaneous Emergence of Entecavir Resistance Mutations in a Nucleoside-Naive Chronic Hepatitis B Patient

Lee, H.W.; Kim, H.J.; Hong, S.P.; Cha, B.K.; Chang, H.Y.; Choi, C.H.; Do, J.H.; Kim, J.G.; Chang, S.K. (Seoul)

Short Communications

385 Genetic and Structural Analysis of HIV-1 Rev Responsive Element Related to V38A and T18A Enfuvirtide Resistance Mutations

Dimonte, S.; Mercurio, F.; Svicher, V.; Perno, C.-F.; Ceccherini-Silberstein, F. (Rome)

391 Pathology Associated with a Human Case of Rabies in the United Kingdom Caused by European Bat Lyssavirus Type-2

Johnson, N.; Brookes, S.M.; Healy, D.M.; Spencer, Y.; Hicks, D.; Nunez, A.; Wells, G. (Addlestone); Fooks, A.R. (Addlestone/Neston)

\section{Erratum}

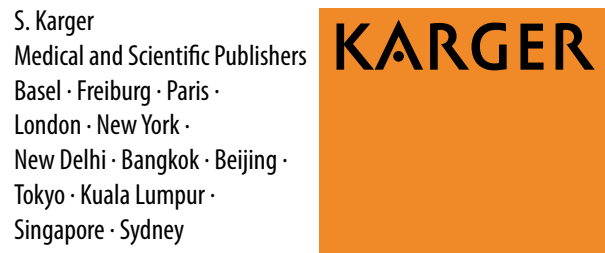




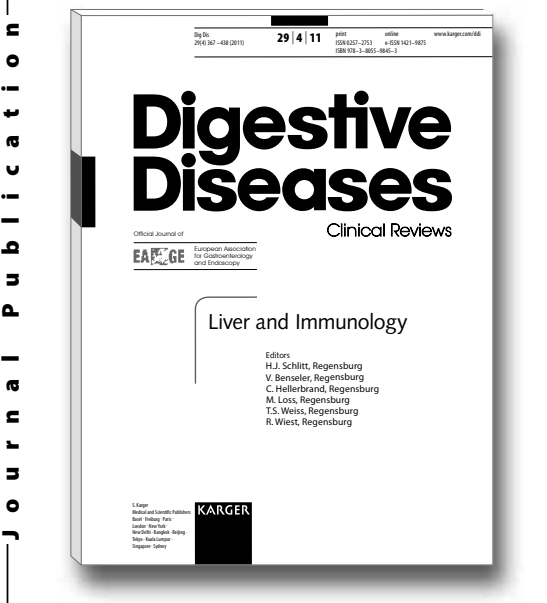

\title{
Liver and Immunology
}

\author{
Editors \\ H.J. Schlitt \\ V. Benseler \\ C. Hellerbrand \\ M. Loss \\ T.S. Weiss \\ R. Wiest
}

\section{Contents}

\section{From Inflammation to Fibrosis}

Modulation of Liver Fibrosis by Adipokines:

Marra, F.; Navari, N.; Vivoli, E.; Galastri, S.;

Provenzano, $A$.

Obesity and Fatty Liver Are 'Grease' for the Machinery of Hepatic Fibrosis: Bosserhoff, A.; Hellerbrand, C.

\section{Transplantation and Regeneration}

Mechanisms Balancing Tolerance and Immunity in the Liver: Böttcher, J.P.; Knolle, P.A.; Stabenow, D.

\section{Autoimmune Liver Disease}

Role of the Hepatic Parenchyma in

Liver Transplant Tolerance: A Paradigm

Revisited: Benseler, V.; Tay, S.S.; Bowen, D.G.;

Bertolino, $P$.

Requirements and Challenges of a Preclinical Autoimmune Hepatitis Mouse Model: Hardtke-Wolenski, M.; Noyan, F.; Jaeckel, E.

Therapeutic Strategies for Autoimmune Hepatitis:Manns, M.P.; Strassburg, C.P.

\section{Viral Hepatitis}

Success and Failure of Virus-Specific T Cell Responses in Hepatitis C Virus Infection: Neumann-Haefelin, C.; Thimme, $R$.

Immune Control of Hepatitis B Virus: Bauer, $T$.; Sprinzl, M.; Protzer, $U$.
Liver and Immunology

Editors: Schlitt, H.J.; Benseler, V.; Hellerbrand, C.;

Loss, M.; Weiss, T.S.; Wiest, R.

72 p., 3 fig., soft cover, 2011

CHF 54.- / EUR 45.- / USD 64.00

Prices subject to change

EUR price for Germany, USD price for USA only

ISBN 978-3-8055-9845-3

e-ISBN 978-3-8055-9846-0

Special Topic Issue:

Digestive Diseases

Vol. 29, No. 4 (2011)

Included in subscription

\section{KARGER}

\section{Please send: __ copy/ies}

Postage and handling free with prepayment

E

Please charge to my credit card

- $\square$ American Express $\square$ Diners $\quad \square$ Eurocard

ᄂ $\square$ MasterCard $\square$ Visa

- Card No.

๑

ర Exp.date

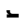

- CVV/CVC

( 3 digits in the signature field on the back of Visa and MasterCard)

\section{$\square$ Check enclosed $\square$ Please bill me}

Orders may be placed with any bookshop, subscription agency, directly with the publisher or through a Karger distributor.
Fax: +41 613061234

S. Karger AG, P.O. Box, CH-4009 Basel (Switzerland) E-Mail orders@karger.ch,www.karger.com

Name/Address:

Date: 


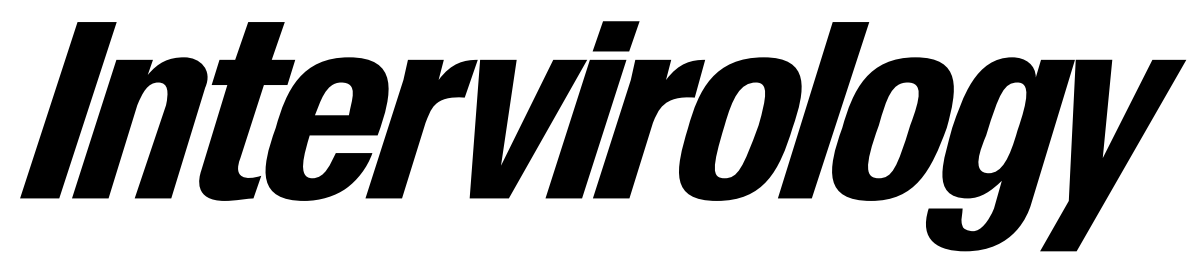

International Journal of Basic and Medical Virology

Founded 1973 by J.L. Melnick

Continued by F. Rapp (1986-1990); M.J. Buchmeier; C.R. Howard (1991-1993) and R.W. Braun (1994-2003)

\section{Editors-in-Chief}

U.G. Liebert, Leipzig

J.-C. Manuguerra, Paris

Editor for Japan/S.E. Asia

O. Hino, Tokyo

\section{Editorial Board}

T. Cunningham, Westmead

O. Hino, Tokyo

J. Kühn, Münster

R. Manservigi, Ferrara

P. Mavromara, Athens

K. Moelling, Zurich

W. Preiser, Tygerberg

G.L. Smith, Cambridge 


\section{Submission}

Only original papers written in English are considered and should be submitted online at:

www.karger.com/int

Should you experience problems with your submission, please contact:

S. Karger AG

Editorial Office 'Intervirology'

PO Box

CH-4009 Basel (Switzerland)

Tel. +41613061344

Fax +4161306 1434

E-Mail int@karger.ch

Names, postal and e-mail addresses of three experts in the appropriate area of research should accompany each manuscript. Selected scientist(s) will be invited to act as referee(s). Referees suggested should not be from the same institution as the author and should have expert knowledge of the subject.

\section{Conditions}

All manuscripts are subject to editorial review. Manuscripts are received with the explicit understanding that they are not under simultaneous consideration by any other publication. Submission of an article for publication implies the transfer of the copyright from the author to the publisher upon acceptance. Accepted papers become the permanent property of 'Intervirology' and may not be reproduced by any means, in whole or in part, without the written consent of the publisher. It is the author's responsibility to obtain permission to reproduce illustrations, tables, etc. from other publications.

Studies involving human subjects: Authors of articles based on trials in humans must first obtain approval from an independent national ethics committee. In addition, a statement that research has been carried out in accordance with the Helsinki Declaration, signed by al authors, must be submitted to the Editorial Office along with the submitted paper.

Consent of patients: If there is any chance that a patient may be identified from an illustration, we ask for the written consent of the patient for publication (or where appropriate from his/her relatives or guardian). Data relating to anonymized tissue and other samples will not normally be considered to be personal information. Publication of research findings connected with such samples does not require patient consent.

Studies involving animals: An article based on trials performed on animals requires a statement that approval from an independent ethics committee has been obtained, signed by all authors.

The Editor-in-Chief recommends that approvals and informed consent, where appropriate, are also declared in the article itself, preferably in the Materials and Methods section.

\section{Arrangement}

Lines should be numbered in the margin.

Title page: The first page of each paper should indicate the title, the authors' names, the institute where the work was conducted, and a short title for use as running head. Full address: The exact postal address of the corresponding author complete with postal code must be given at the bottom of the title page. Please also supply phone and fax numbers, as well as e-mail address.

Key words: Please supply 3-10 key words in English that reflect the content of the paper.
Abstract: Each paper needs an abstract of up to 200 words structured with subheadings as follows $\mathrm{Ob}$ jective(s), Methods, Results, Conclusion(s).

Footnotes: Avoid footnotes. When essential, they are numbered consecutively and typed at the foot of the appropriate page.

Body of the paper: Manuscripts should then be divided into the following subdivisions: Introduction, Materials and Methods (as brief as possible), Results, Discussion, Acknowledgments and References.

Tables and illustrations: Tables and illustrations (both numbered in Arabic numerals) should be prepared on separate sheets. Tables require a heading and figures a legend, also prepared on a separate sheet. Due to technical reasons, figures with a screen background should not be submitted. When possible, present several illustrations en bloc for reproduction (max. size $180 \times 223 \mathrm{~mm}$ ) or provide crop marks. B/w half-tone and color illustrations must have a final resolution of $300 \mathrm{dpi}$ after scaling, line drawings one of $800-1200 \mathrm{dpi}$

\section{Color illustrations}

Online edition: Color illustrations are reproduced free of charge. In the print version, the illustrations are reproduced in black and white. Please avoid referring to the colors in the text and figure legends.

Print edition: Up to 6 color illustrations per page can be integrated within the text at CHF 800.- per page.

References: In the text identify references by Arabic numerals [in square brackets]. Material submitted for publication but not yet accepted should be noted as 'unpublished data' and not be included in the reference list. The list of references should include only those publications which are cited in the text. Do not alphabetize; number references in the order in which they are first mentioned in the text. The surnames of the authors followed by initials should be given. There should be no punctuation other than a comma to separate the authors. Preferably, please cite all authors. Abbreviate journal names according to the Index Medicus system. Also see International Committee of Medical Journal Editors: Uniform requirements for manuscripts submitted to biomedical journals (www.icmje.org).

\section{Examples}

(a) Papers published in periodicals: Sun J, Koto $\mathrm{H}$, Chung KF: Interaction of ozone and allergen challenges on bronchial responsiveness and inflammation in sensitised guinea pigs. Int Arch Allergy Immunol 1997;112:191195.

(b) Papers published only with DOI numbers:

Theoharides TC, Boucher W, Spear K: Serum interleukin-6 reflects disease severity and osteoporosis in mastocytosis patients. Int Arch Allergy Immunol DOI: $10.1159 / 000063858$

(c) Monographs: Matthews DE, Farewell VT: Using and Understanding Medical Statistics, ed 3, revised. Basel, Karger, 1996.

(d) Edited books: Parren PWHI, Burton DR: Antibodies against HIV-1 from phage display libraries: Mapping of an immune response and progress towards antiviral immunotherapy; in Capra JD (ed): Antibody Engineering. Chem Immunol. Basel, Karger, 1997, vol 65, pp 18-56.

Reference Management Software: Use of EndNote is recommended for easy management and formatting of citations and reference lists.

\section{Digital Object Identifier (DOI)}

S. Karger Publishers supports DOIs as unique identifiers for articles. A DOI number will be printed on the title page of each article. DOIs can be useful in the future for identifying and citing articles published online without volume or issue information. More information can be found at www.doi.org.

\section{Supplementary Material}

Supplementary material is restricted to additional data that are not necessary for the scientific integrity and conclusions of the paper. Please note that all supplementary files will undergo editorial review and should be submitted together with the original manuscript. The Editors reserve the right to limit the scope and length of the supplementary material. Supplementary material must meet production quality standards for Web publication with out the need for any modification or editing. In general, supplementary files should not exceed $10 \mathrm{MB}$ in size. All figures and tables should have titles and legends and all files should be supplied separately and named clearly. Acceptable files and formats are: Word or PDF files, Exce spreadsheets (only if the data cannot be converted properly to a PDF file), and video files (.mov, .avi, .mpeg).

\section{Nomenclature of viruses}

Names used for viruses should be those approved by the International Committee on Taxonomy of Viruses (ICTV) and published in Fauquet CM, Mayo MA, Maniloff J, Desselberger U, Ball LA (eds): Virus Taxonomy, VIIIth Report of the International Committee on Taxonomy of Viruses, ed 2, revised (New York, Academic Press, 2005). If desired, synonyms may be added in parentheses when the name is first mentioned. Approved generic (or group) and family names should also be used.

\section{Short Communications}

In addition to regular papers, a section of the journal will publish brief communications of important findings, in which illustrative material should be limited. Such notes should include a brief summary and key words, the body of the report (without any subdivisions), brief acknowledgment, and a few selected references. The general style and submission procedures outlined above apply to the short communication.

\section{Commentaries}

Short commentaries of an editorial nature may be submitted to the journal. In these communications, usual manuscript subdivisions do not apply, and a summary statement is not needed; however, a very brief reference list may be included.

\section{Letters to the Editor}

This section provides readers with a forum in which to exchange ideas and comments on papers published in the journal. Letters should be no longer than $1-1 \frac{1}{2}$ doublespaced pages, including a maximum of six references, and do not require abstracts or formal section headings.

\section{Page Charges}

There are no page charges for papers of 6 or fewer printed pages (including tables, illustrations and references) Each additional complete or partial page is charged to the author at CHF 325.-. The allotted size of a paper is equal to approx. 16 manuscript pages (including tables, illustrations and references).

\section{E-pub First}

All articles are published electronically ahead of print with a DOI number and are supplemented later with the definite reference of the printed version. The articles become available immediately after the authors' approval to publication, with the added advantage of being citable much earlier than in print. Authors can influence the time of appearance by promptly returning the proofs.

\section{KARGER}

Fax +4161306 1234

E-Mail karger@karger.ch

www.karger.com 


\section{Author's Choice ${ }^{\mathrm{TM}}$}

Karger's Author's Choice ${ }^{\mathrm{TM}}$ service broadens the reach of your article and gives all users worldwide free and full access for reading, downloading and printing at www. karger.com. The option is available for a one-time fee of CHF 3000.-, which is a permissible cost in grant allocation. More information can be found at www.karger.com/ authors_choice.

\section{NIH-Funded Research}

The U.S. National Institutes of Health (NIH) mandates under the NIH Public Access Policy that final, peer-reviewed manuscripts appear in its digital database within 12 months of the official publication date. As a service to authors, Karger submits the final version of your article on your behalf to PubMed Central. For those selecting our premium Author's Choice ${ }^{\mathrm{TM}}$ service, we will send your article immediately upon publishing, accelerating the accessibility of your work without the usual embargo. More details on NIH's Public Access Policy is available at http://publicaccess.nih.gov/policy.htm

\section{Self-Archiving}

Karger permits authors to archive their pre-prints (i.e. pre-refereeing) or post-prints (i.e. final draft post-refereeing) on their personal or institution's servers, provided the following conditions are met: Articles may not be used for commercial purposes, must be linked to the publisher's version, and must acknowledge the publisher's copyright. Authors selecting Karger's Author's Choice ${ }^{\mathrm{TM}}$ feature, however, are also permitted to archive the final, published version of their article, which includes copyediting and design improvements as well as citation links.

\section{Proofs}

Unless indicated otherwise, proofs are sent to the corresponding author and should be returned with the least possible delay. Alterations other than the correction of printer's errors are charged to the author.

\section{Reprints}

Order forms and a price list are sent to the author with the proofs. Orders submitted after the issue is printed are subject to considerably higher prices.
Standard forms of abbreviations: The standard abbreviations used for measurements of weight, length, volume, and time (i.e., $\mathrm{mg}, \mathrm{cm}, \mathrm{ml}$, and $\mathrm{min}$ ) are acceptable and may be used without definition. The abbreviations listed also require no preliminary definition. Please note that punctuation is not needed. When using other abbreviations, the name should be spelled out in full at the first mention, and followed with the abbreviation in parentheses.

$\begin{array}{ll}\text { A, C, G, T, U } & \begin{array}{l}\text { (Fahrenheit will not be used) } \\ \text { adenine, cytosine, guanine, } \\ \text { thymine, uracil }\end{array} \\ \text { AMP } & 5^{\prime} \text {-monophosphates of adenosine } \\ \quad \text { CMP } & \text { - cytidine } \\ \text { GMP } & \text { - guanosine } \\ \text { TMP } & \text { - thymidine } \\ \text { UMP } & \text { - uridine } \\ \text { ADP, etc. } & \text { adenosine } 5^{\prime} \text {-diphosphate, etc. } \\ \text { ATP, etc. } & \text { adenosine 5'-triphosphate, etc. } \\ \text { CPE } & \text { cytopathic effect } \\ \text { DEAE-cellulose } & \text { diethylaminoethylcellulose } \\ \text { DNA } & \text { deoxyribonucleic acid } \\ \text { DNase } & \text { deoxyribonuclease } \\ \text { EDTA } & \text { ethylenediaminetetra-acetate } \\ \text { EOP } & \text { efficiency of plating } \\ g & \text { acceleration of gravity } \\ \text { ID } & \text { median infective dose } \\ \text { LD }_{50} & \text { median lethal dose } \\ M & \text { molar }\end{array}$

$\begin{array}{ll}\text { MEM } & \text { minimum essential medium } \\ \text { MOI } & \text { multiplicity of infection } \\ \text { ng } & \text { nanogram } \\ \text { nm } & \text { nanometer }\left(10^{-9} \mathrm{~m}\right) \\ \text { PAGE } & \text { polyacrylamide gel electrophoresis } \\ \text { PFU } & \text { plaque forming units } \\ \text { RNA } & \text { ribonucleic acid } \\ \text { RNase } & \text { ribonuclease } \\ \text { rpm } & \text { revolutions per minute } \\ \text { SD } & \text { standard deviation } \\ \text { SDS } & \text { sodium dodecyl sulfate } \\ \text { sp gr } & \text { specific gravity } \\ \text { TCD } & \text { median tissue culture } \\ & \text { infective dose } \\ \text { Tris } & \text { tris (hydroxymethyl) } \\ & \text { aminomethane }(2 \text {-amino-2- } \\ \text { UV } & \text { hydroxymethylpropane-1,3-diol }) \\ \text { V } & \text { ultraviolet } \\ \text { W } & \text { volt } \\ & \text { watt }\end{array}$

\begin{tabular}{|c|c|c|c|c|}
\hline $\begin{array}{l}\text { Series Editor } \\
\text { Doerr, H.W. (Frankfurt/Main) }\end{array}$ & \multicolumn{3}{|c|}{$\begin{array}{l}\text { Compact and thorough reference volumes for virologists and non-virologists alike } \\
\text { A skilful selection of topics of exceptional importance and a panel of acknowledged experts } \\
\text { as authors have ensured an outstanding reputation for this series. Each monograph, centered } \\
\text { on an active area of virologic research, provides a critical evaluation of recent progress and } \\
\text { a useful commentary on the direction of future research. Characterized by a consistently high } \\
\text { standard of scholarship and clear presentation of content, volumes in this series have proved } \\
\text { their enduring value as convenient reference tools for both virologists working in the field and } \\
\text { scientists working in allied areas. }\end{array}$} & 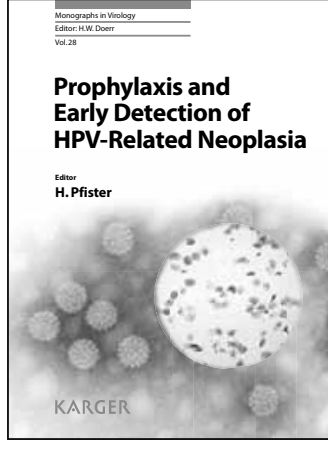 \\
\hline $\begin{array}{l}\text { Monographs in Virology } \\
\text { ISSN 0077-0965 } \\
\text { Listed in bibliographic services, } \\
\text { including Current Contents }{ }^{\oplus} \text {, } \\
\text { Reference Update, } \\
\text { Biological Abstracts. }\end{array}$ & $\begin{array}{l}\text { Vol. 28: Prophylaxis and Early } \\
\text { Detection of HPV-Related } \\
\text { Neoplasia } \\
\text { Editor: Pfister, H. (Cologne) } \\
\text { VIII + } 140 \text { p., } 27 \text { fig., } 21 \text { in color, } \\
13 \text { tab., hard cover, } 2012 \\
\text { ISBN 978-3-8055-9964-1 } \\
\text { e-ISBN 978-3-8055-9965-8 }\end{array}$ & $\begin{array}{l}\text { Vol. 27: Avian Influenza } \\
\text { Editors: Klenk, H.-D.; } \\
\text { Matrosovich, M.N. (Marburg); } \\
\text { Stech, J. (Greifswald) } \\
\text { VIII + } 294 \text { p., } 35 \text { fig., } 16 \text { in color, } \\
12 \text { tab., hard cover, } 2008 \\
\text { CHF 249.- / EUR 208.- / USD } 293.00 \\
\text { ISBN 978-3-8055-8501-9 } \\
\text {... An outstanding collection of } \\
\text { articles that should have a place in } \\
\text { every animal or human influenza } \\
\text { research laboratory.' } \\
\text { Clinical Infectious Disease }\end{array}$ & $\begin{array}{l}\text { Vol. 26: Herpes Zoster } \\
\text { Recent Aspects of Diagnosis and } \\
\text { Control } \\
\text { Editors: Gross, G. (Rostock); } \\
\text { Doerr, H.W. (Frankfurt) } \\
\text { X+194 p., } 52 \text { fig., } 24 \text { in color, } 18 \text { tab., } \\
\text { hard cover, 2006 } \\
\text { CHF 198.- / EUR 165.- / USD } 233.00 \\
\text { ISBN 978-3-8055-7982-7 }\end{array}$ & $\begin{array}{l}\text { Vol. 25: Models of } \\
\text { Viral Hepatitis } \\
\text { Editors: von Weizsäcker, F. (Freiburg); } \\
\text { Roggendorf, M. (Essen) } \\
\text { VIII + } 164 \text { p., } 27 \text { fig., } 1 \text { in color, } 5 \text { tab., } \\
\text { hard cover, } 2005 \\
\text { CHF 162.- / EUR 135.- / USD } 191.00 \\
\text { ISBN 978-3-8055-7809-7 }\end{array}$ \\
\hline $\begin{array}{l}\text { Read it online: } \\
\text { www.karger.com/movir }\end{array}$ & \multicolumn{4}{|c|}{$\begin{array}{l}\text { Prices subject to change } \\
\text { EUR price for Germany, USD price for USA only }\end{array}$} \\
\hline
\end{tabular}




\section{Intervirology}

ISSN Print Edition: $0300-5526$ ISSN Online Edition: 1423-0100

Journal Homepage: www.karger.com/int

Publication Data: 'Intervirology' is published 6 times a year. Volume 55 with 6 issues appears in 2012 .

Copyright: (c) 2012 S. Karger AG, Basel (Switzerland). All rights reserved. No part of this publication may be translated into other languages, reproduced or utilized in any form or by any means, electronic or mechanical, including photocopying, recording, microcopying, or by any information storage and retrieval system, without permission in writing from the publisher or, in the case of photocopying, direct payment of a specified fee to the Copyright Clearance Center.

Disclaimer: The statements, opinions and data contained in this publication are solely those of the individual authors and contributors and not of the publisher and the editor(s). The appearance of advertisements in the journal is not a warranty, endorsement, or approval of the products or services advertised or of their effectiveness, quality or safety. The publisher and the editor(s) disclaim responsibility for any injury to persons or property resulting from any ideas, methods, instructions or products referred to in the content or advertisements.
Subscription Rates: Subscriptions run for a full calendar year. Prices are given per year. Personal subscription:

Print or Online

CHF 635.-

EUR 508.00

USD 616.00

Print+Online combined CHF 683.-

EUR 546.-

USD 663.00

postage and handling (added to print and print+online)

CHF 40.80 Europe, CHF 60.- Overseas

EUR 31.20

USD 56.40

Institutional subscription

Print or Online

Print+Online combined

CHF 1813.

EUR 1450.-

CHF 1994.-

USD 1760.00

postage and handling (added to print and print+online)

CHF 51.- Europe, CHF 75.- Overseas

EUR 39.-

USD 70.50

Airmail surcharge: CHF 51.- / USD 48.00

Discount subscription prices:

- International Union of Microbiological Societies

- American Society for Virology
Back Volumes and Single Issues: Information on availability and prices of single print issues and print or electronic back volumes can be obtained from Customer Service at service@karger.ch.

Bibliographic Indices: This journal is regularly listed in bibliographic services, including Current Contents ${ }^{\circledR}$ and PubMed/MEDLINE.

Photocopying: This journal has been registered with the Copyright Clearance Center (CCC), as indicated by the code appearing on the first page of each article. For readers in the US, this code signals consent for copying of articles for personal or internal use, or for the personal or internal use of specific clients, provided that the stated fee is paid per copy directly to

Copyright Clearance Center Inc.

222 Rosewood Drive

Danvers, MA 01923 (USA)

A copy of the first page of the article must accompany payment. Consent does not extend to copying for general distribution, for promotion, for creating new works, or for resale. In these cases, specific written permission must be obtained from the copyright owner,

S. Karger AG, P.O. Box

CH-4009 Basel (Switzerland).

\section{Subscription Orders:}

Orders can be placed at agencies,

bookstores, directly with the Publisher

\section{S. Karger AG}

Medical and Scientific Publishers

P.O. Box

CH-4009 Basel

Switzerland

(for courier services only:

Allschwilerstrasse 10

CH-4055 Basel)

t: +416130611 11

f: +41613061234

e: karger@karger.ch

w: www.karger.com or further Karger offices

or representatives:

\section{Germany}

S. Karger GmbH

Postfach

79095 Freiburg

Deutschland

(Hausadresse: Wilhelmstrasse 20A,

79098 Freiburg)

t: +49761452070

f: $\quad+497614520714$

e: information@karger.de

w: www.karger.de

\section{Japan}

Karger Japan, Inc

Shiba Daimon Asahi Bldg. 2F

1-2-23 Shiba Daimon

Minato-ku

Tokyo 105-0012

Japan

$\mathrm{t}:+81364356242$

f: +81364356244

e: publisher@karger.jp

w: www.karger.jp

Change of Address:

Both old and new address should be sent to the subscription source.

USA

S. Karger Publishers, Inc.

26 West Avon Road

P.O. Box 529

Unionville, CT 06085

USA

Toll free: +18008285479

t: +18606757834

f. +18606757302

e: karger@snet.net

France

Librairie Médi-Sciences Sarl

36, bd de Latour-Maubourg

75007 Paris

France

t: $+33(0) 145514258$

f: $\quad+33(0) 145560780$

f: $+33(0) 145560780$

w: www.medi-sciences.fr

Gulf Council Countries, Iran,

Middle East, North Africa, Turkey

Trans Middle East International

Distribution Co. Ltd.

Kasha

134 Queen Rania Al Abdullah Street

Jordan Trade Center Bldg. 3rd Floor

P.O. Box 2376

Amman 11953

Jordan

t: +96265153467

f: +96265153472

e: info@kasha.cc

w: www.KaShaonline.com
South East Asia, China and Taiwan Karger Regional Office (Malaysia) CEO Suite Kuala Lumpur Quill 7,27th Floor

Jalan Stesen Sentral 5

KL Sentral

Kuala Lumpur 50470

Malaysia

t: +60327766803

f: +60327766999

e: service@karger.cn; r.chew@karger.cn

\section{Karger China}

10th Floor, Twin Towers (East)

B12 Jianguomenwai Avenue

Beijing 100022

China

$\mathrm{t}: \quad+861051235033$

f: +861051235122

e: service@karger.cn; r.chew@karger.cn

w: www.karger.cn

India, Bangladesh, Sri Lanka

Medscience India

Plot No. 17, Yusuf Sarai Market

B.L. Glass Building, 2nd Floor

Sri Aurobindo Marg

New Delhi 110016

India

t: +911146029633

f: +911146029634

c: +919891052128

e: medsci.india@gmail.com

\section{KARGER}

Fax +41 613061234

E-Mail karger@karger.ch

www.karger.com
(C) 2012 S. Karger AG, Basel

The Journal Home Page is available at:

www.karger.com/int 


\section{Contents}

See the journal website for contents

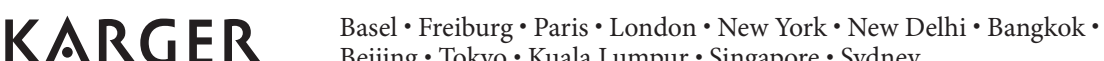
Beijing $\cdot$ Tokyo $\cdot$ Kuala Lumpur $\cdot$ Singapore $\cdot$ Sydney 


\section{VIIRAL \\ HEPATITIS \\ The Viral Hepatitis Congress 2012}

CONGRESS

7-9 September 2012, J.W. Goethe University, Frankfurt, Germany

www.viral-hep.org for more information

Educational 21/2-day meeting focusing on the practical treatment of patients with viral hepatitis

Engaging scientific programme with time for interaction and discussion

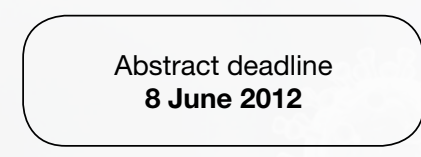

Standard registration deadline 24 August $2012-£ 425$

\section{T H E




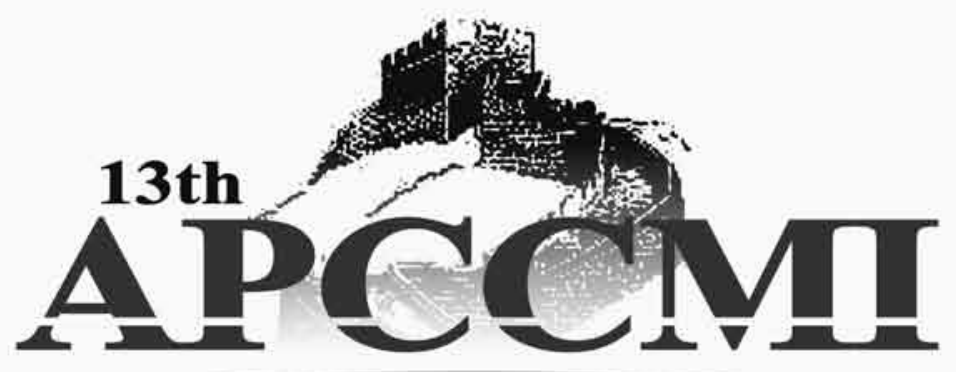

BEIJING, 2012

\section{BEIJING, CHINA}

\section{October 25-28, 2012 China National Convention Center}

Abstracts for 13th Asia-Pacific Congress of Clinical Microbiology and Infection (13th APCCMI) are highly welcomed!

CALLFORABSTRACIS

Collaboration in the Management of Infections:

Right Ideas, Right Actions, and Right Now

www.apccmi2012.org

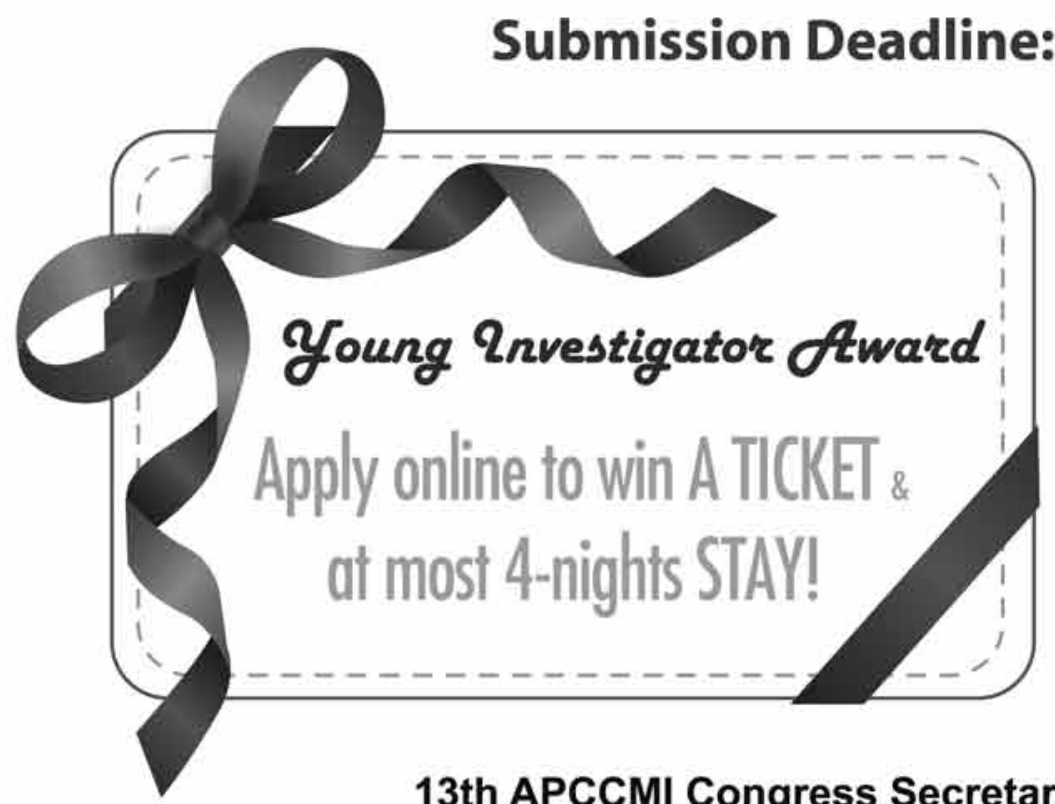

13th APCCMI Congress Secretariat: Ms. Rita Yu

旁 Tel: +886-2-8502-7087 ext. 25 / Email: service@apccmi2012.org
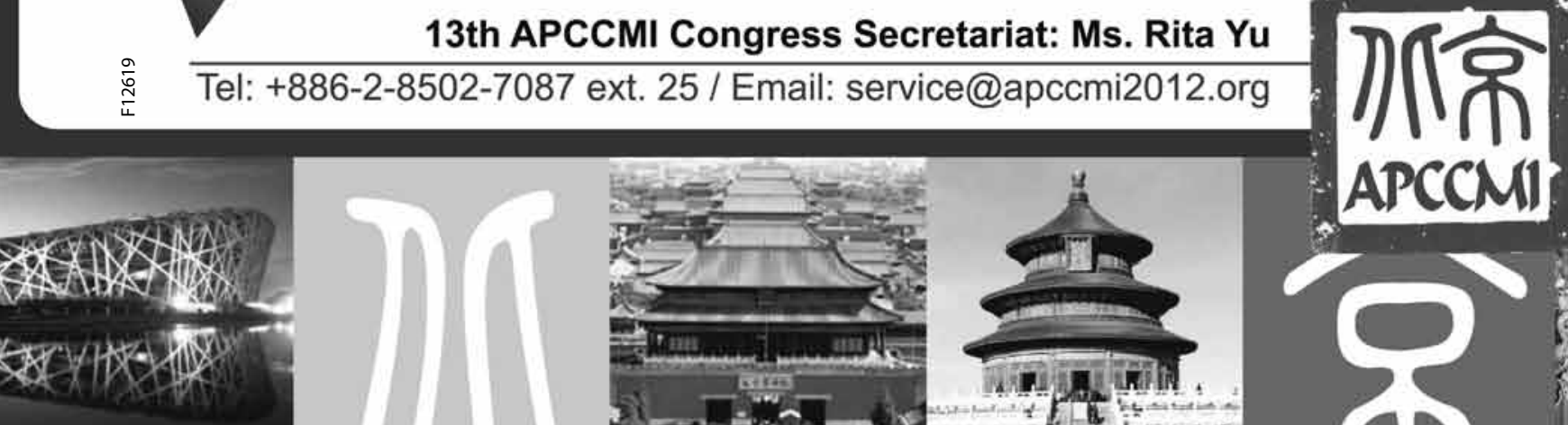


\section{DVV}

\section{Deutsche Vereinigung zur Bekämpfung der Viruskrankheiten}

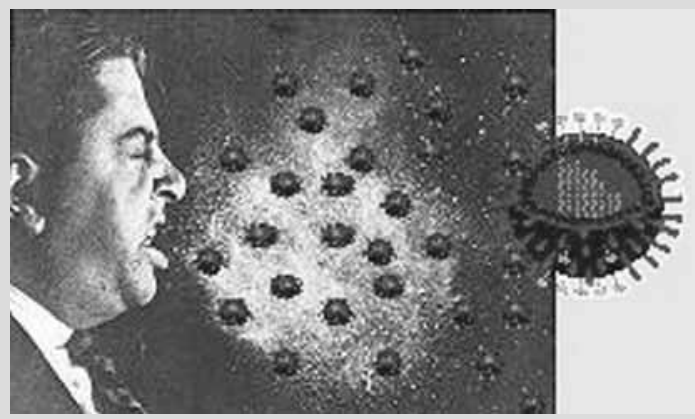

Einladung

\section{Deutscher Influenza-Kongress} mit internationaler Beteiligung

\section{Jahrestagung der DVV}

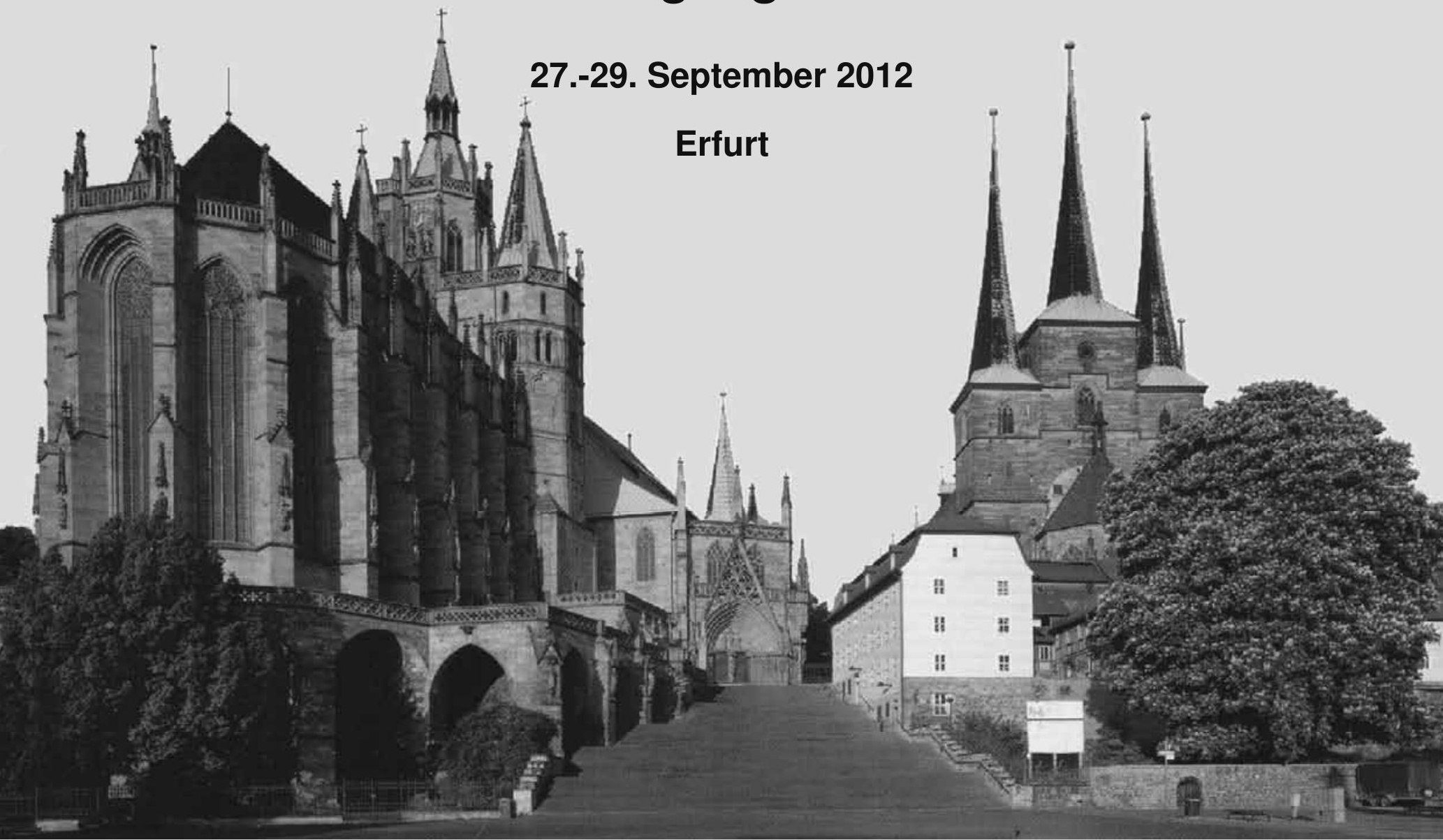




\section{Influenza2012: \\ One Influenza, One World}

11-13 September 2012, St Hilda's College, Oxford, UK http://www.Ipmhealthcare.com/Influenza2012/InfluenzaHome.htm

\section{Key Conference Topics}

- Molecular virology

- Host-pathogen interactions

- Mathematical modelling

- Surveillance and contingency strategies

- Antivirals, vaccination and immunology

- Socio-economics

-Technology focus

\section{Scientific Advisory Board}

- Professor Robert Webster

- Dr llaria Capua

- Professor David Swayne

- Dr Dennis Alexander

- Professor Anthony Nash

- Dr John McCauley

- Professor John Oxford

- Dr Munir lqbal

\section{Keynote Speakers}

- Professor Robert Webster FRS

- Professor Dr Hans-Dieter Klenk

- Professor ADME Osterhaus

Distinguished Faculty also includes

- Professor Thomas Mettenleiter

- Professor Mikhail Matrosovic

- Professor Wendy Barclay

- Professor Hafez M Hafez

- Professor John Oxford

- Professor Ron Fouchier

- Dr Laurence Tiley

- Dr Munir lqbal

- Dr Sharon Brookes

- Dr Giovanni Maga

Please visit the conference website for full agenda.

For regular updates please visit the conference website

For registration, accommodation, sponsorship and any other conference inquiries, please write to:

Dr Muhammad Sohail on

FluOxford@gmail.com

Project managed by: 


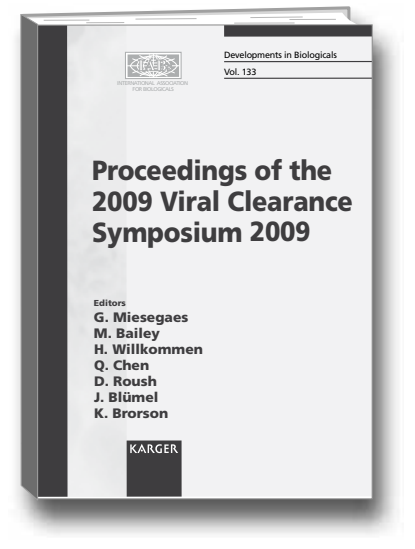

Main Headings

- Overview

- Protein A Chromatography

- Low pH Treatment

- Anion Exchange Chromatography (AEX)

- Alternative Chromatographic Methods

- Virus Inactivation by Detergents

- Virus Filtration

- Closing Remarks and Prioritization of the ,Next Steps'

\section{Viral Clearance Symposium 2009}

International Symposium, Indianapolis, Ind., March 2009: Proceedings

\author{
Editors \\ George Miesegaes \\ Mark Bailey \\ Hannelore Willkommen \\ Qi Chen \\ David Roush \\ Johannes Blümel \\ Kurt Brorson
}

The 2009 Viral Clearance Symposium (Indianapolis, Ind., USA) was held to interactively discuss methods for virus removal and inactivation during biopharmaceutical manufacture. Its origin was the result of worldwide regulatory and industry recognition that challenges, gaps, and opportunities for improvement exist, which if formally addressed could benefit the field as a whole. The symposium began with presentations by the FDA (USA) and the Paul Ehrlich Institute (PEl, Germany), which highlighted viral clearance study information reported in regulatory submissions. In these two presentations, and a subsequent series of brief industry presentations covering various unit operations, it was made clear that many unit operations are quite effective in clearing viruses. This was particularly true of low $\mathrm{pH}$ inactivation, anion exchange chromatography, and virus filtration. Moreover, the follow-up discussions at the end of each session, and the wrap-up at the end of the symposium, aimed to synthesize the regulatory data mining knowledge base with the industry-generated data. The symposium also revealed a number of unknowns in the field which were defined and prioritized, and served as potential action items for future experimental studies.

www.karger.com/debis

Developments in Biologicals, Vol. 133 Edited by the International Association for Biologicals (IABS)

ISSN 1424-6074 / e-ISSN 1662-2960

Viral Clearance Symposium 2009 International Symposium, Indianapolis, Ind., March 2009: Proceedings

Editors: Miesegaes, G.; Bailey, M.; Willkommen, H.;

Chen, Q.; Roush, D.; Blümel, J.; Brorson, K.

XII + 104 p., 36 fig., 38 tab., soft cover, 2010

CHF 105.- / EUR 88.- / USD 124.00

Prices subject to change

EUR price for Germany, USD price for USA only

ISBN 978-3-8055-9682-4

KARGER $\rightarrow$ Please send: __ copy/ies

Postage and handling free with prepayment

E

Payment:

- Please charge to my credit card

- $\square$ American Express $\square$ Diners $\square$ Eurocard

ᄂ $\square$ MasterCard $\square$ Visa

- Card No.

o

- Exp. date

- $\mathrm{CVV} / \mathrm{CVC}$

(3 digits in the signature field on the back of Visa and MasterCard)

$\square$ Check enclosed $\square$ Please bill me

Orders may be placed with any bookshop, subscription agency, directly with the publisher or through a Karger distributor.
Fax: +41 613061234

S. Karger AG, P.O. Box, $\mathrm{CH}-4009$ Basel (Switzerland) E-Mail orders@karger.ch,www.karger.com

Name/Address: 


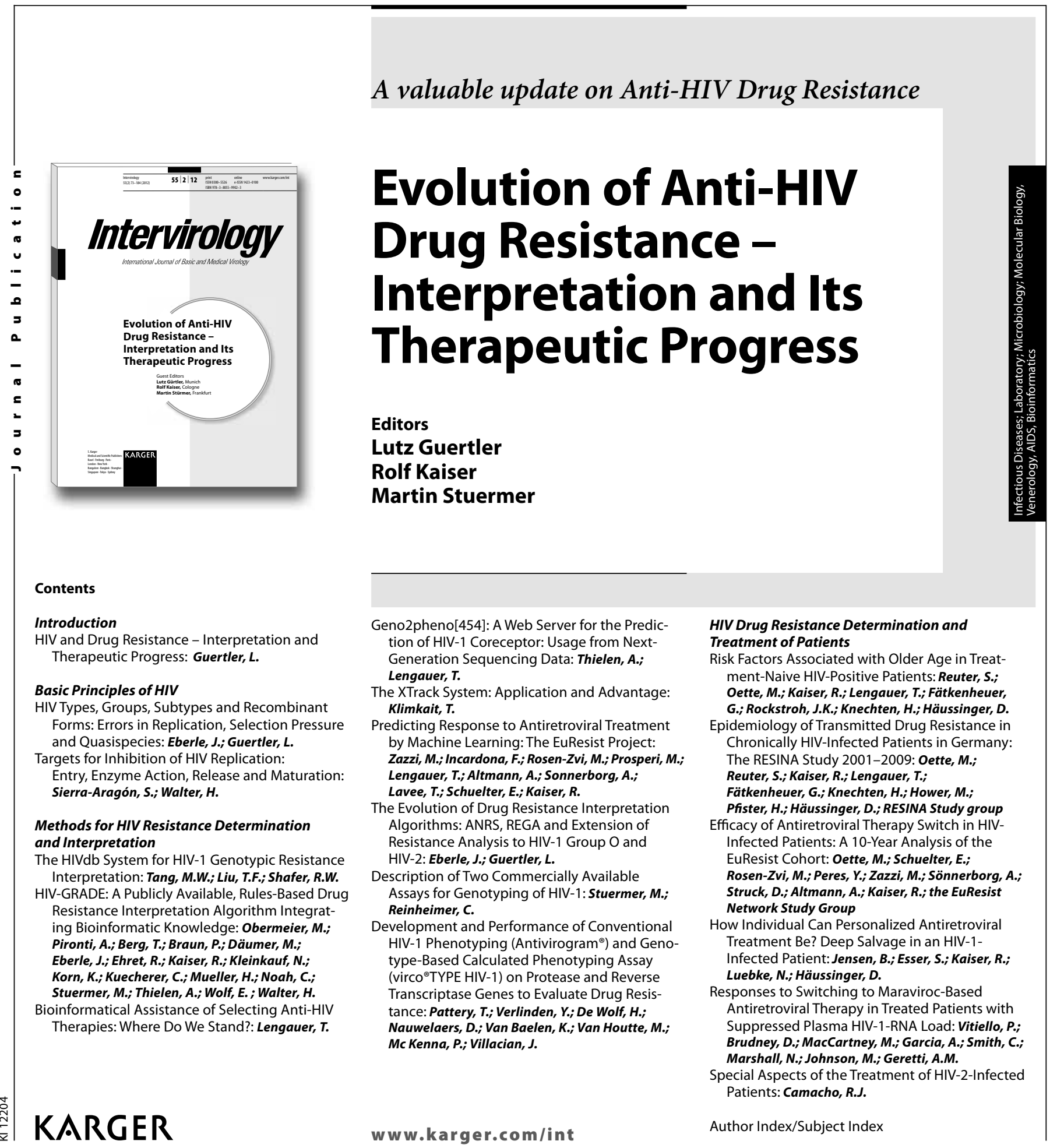

Evolution of Anti-HIV Drug Resistance Interpretation and Its Therapeutic Progress Editors: Guertler, L. (Munich); Kaiser, R. (Cologne); Stuermer, M. (Frankfurt)

112 p., 28 fig., 11 in color, 20 tab., soft cover , 2012 CHF 39.- / EUR 33.- / USD 46.00

Prices subject to change

EUR price for Germany, USD price for USA only

ISBN 978-3-8055-9902-3

e-ISBN 978-3-8055-9903-0

Special Topic Issue

Intervirology

Vol. 55, No. 2 (2012)

Included in subscription

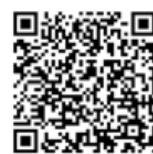

\section{$\rightarrow$ Please send: copy/ies}

Postage and handling free with prepayment

E - Payment:

Please charge to my credit card

- $\square$ American Express $\square$ Diners

ᄂ $\square$ MasterCard $\square$ Visa

- Card No.

๑

- Exp date:

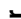

- CVV/CVC

( 3 digits in the signature field on the back of Visa and MasterCard)

$\square$ Check enclosed $\quad \square$ Please bill me

Orders may be placed with any bookshop, subscription agency, directly with the publisher or through a Karger distributor.
HIV Drug Resistance Determination and ts: Reuter, $S$. Oette, M.; Kaiser, R.; Lengauer, T.; Fätkenheuer, , Rockstroh, J.K.; Knechten, $H_{*} ;$ Häussinger, $D$. demiology of Transmitted Drug Resistance in

gauer, $T$ Rosen-Zvi, Mi, Peres, $Y$, Zazzi, M Sönnerborg, A Struck, D.; Altmann, A.; Kaiser, R.; the EuResist Treatment Be? Dalvage in an HIV-1 Infected Patient: Jensen, B.; Esser, S.; Kaiser, R.;

Author Index/Subject Index
Fax: +41613061234

S. Karger AG, P.O. Box, CH-4009 Basel (Switzerland) E-Mail orders@karger.ch,www.karger.com

Name/Address: 


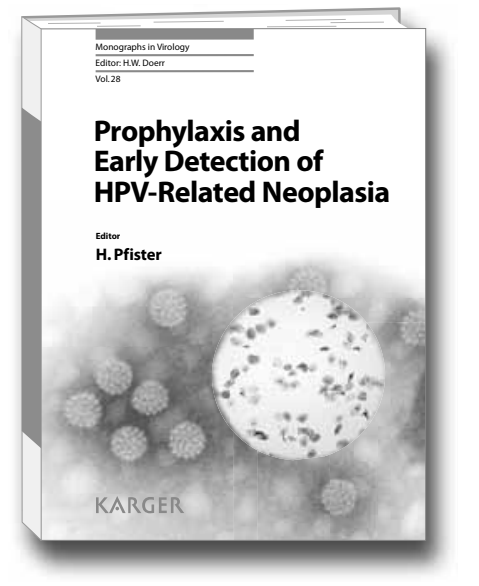

Human papillomaviruses (HPV) are a heterogeneous and still growing virus family. Topical research results on the replication cycle and carcinogenic mechanisms allow a better understanding of current prevention strategies. Written by leading experts, this volume of Monographs in Virology provides up-to-date information on the prevention of papillomavirus-induced cancers by prophylactic antiviral vaccines and early detection of precancerous lesions.

A major section covers the tremendous clinical burden due to HPV infections: genital warts and laryngeal papillomas, the most notorious cervical cancer, but also further anogenital and tonsillar cancer, the incidence of which increased steeply during the last decades. Additionally, a section on prevention addresses the subject cytology - new concepts of biomarker development, detection of HPV DNA and RNA as well as their use in primary screening for early detection of precancerous lesions. Finally the book closes with a topical discussion of the most intriguing primary prevention of HPV infection by vaccination.

As new perspectives for the prevention of HPVrelated neoplasia raised great public interest, this book will be of value to clinicians and practitioners in gynecology, dermatology, urology and ENT, to pathologists, laboratory physicians, medical students, and public health authorities.

\section{Prophylaxis and Early Detection of HPV-Related Neoplasia}

\author{
Editor \\ Herbert Pfister
}

\section{Contents}

\section{Foreword: Pfister, $\boldsymbol{H}$.}

Virology and Pathogenesis: Pfister, $\boldsymbol{H}$.

Epidemiology of Mucosotropic Papillomaviruses: Gissmann, $\boldsymbol{L}$.

Clinical Aspects of Low-Risk HPV Infections

- Condylomata Acuminata: Gross, G.

- Recurrent Respiratory Papillomatosis: Wittekindt, C.; Wagner, S.; Klussmann, J.P.

Clinical Aspects of High-Risk HPV Infections - Cervical Cancer and Intraepithelial Neoplasia: Schneider, A.; Köhler, C.; Chiantera, V.; Vercellino, $F$.

- Cancer and Intraepithelial Neoplasia of the Vulva and Vagina: Petry, K.U.

- Penile Cancer and Penile Intraepithelial Neoplasia: Gross, G.F.

- Anal Cancer and Intraepithelial Neoplasia: Wieland, U.; Kreuter, A.

- Tonsillar Cancer: Klussmann, J.P.; Wagner, S.; Wittekindt, C.
Diagnosis for Early Detection

- Cytology: Ikenberg, $\boldsymbol{H}$.

- Concepts of Biomarker Development: von Knebel Doeberitz, M.; Vinokurova, S.; Reuschenbach, $M$.

- Detection of Human Papillomavirus DNA and RNA: Ikenberg, $\boldsymbol{H}$.

- Human Papillomavirus Testing in Primary Screening for Cervical Cancer: Petry, K.U.

Primary Prevention by Vaccination: Kaufmann, A.M.; Gissmann, L.

Author Index Subject Index
Monographs in Virology, Vol. 28 Series Editor: Doerr, H.W. (Frankfurt a.M.) ISSN 0077-0965 / e-ISSN 1662-3851

\section{Prophylaxis and Early Detection of} HPV-Related Neoplasia Editor: Pfister, H. (Cologne) VIII + 140 p., 27 fig., 21 in color, 13 tab., hard cover, 2012 CHF 119.- / EUR 99.- / USD 140.00

Prices subject to change

EUR price for Germany, USD price for USA only

ISBN 978-3-8055-9964-1

e-ISBN 978-3-8055-9965-8 $\rightarrow$ Please send: ___ copy/ies

Postage and handling free with prepayment

E

Payment:

Please charge to my credit card

- Please charge to my credit card

$\square$ MasterCard $\square$ Visa

- Card No.

(1)

O Exp. date:

- CVV/CVC

( 3 digits in the signature field on the back of Visa and MasterCard)

$\square$ Check enclosed $\quad \square$ Please bill me

Orders may be placed with any bookshop, subscription agency, directly with the publisher or through a Karger distributor.
Fax: +41613061234

S. Karger AG, P.O. Box, CH-4009 Basel (Switzerland) E-Mail orders@karger.ch,www.karger.com

Name/Address: 


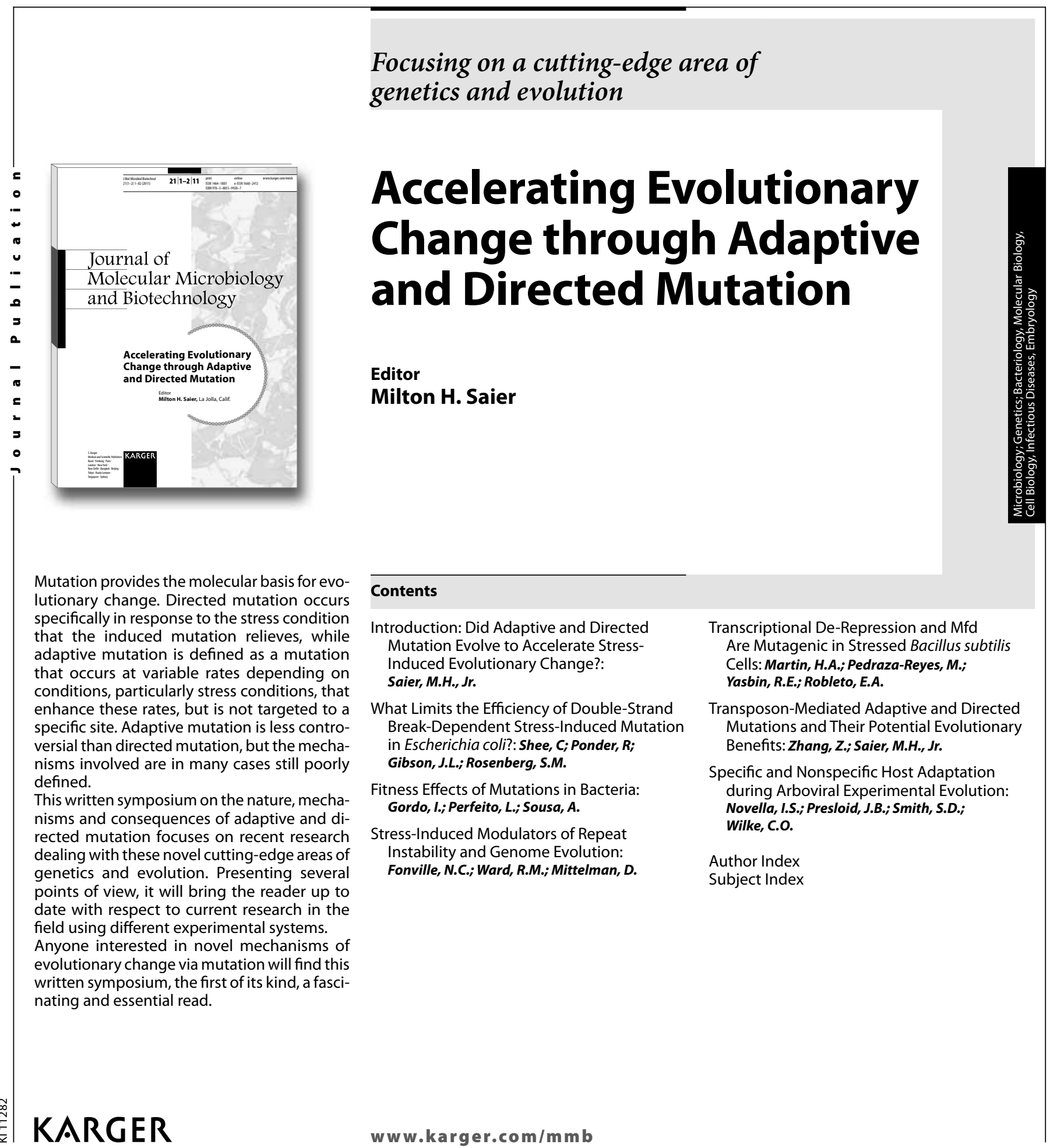

\section{Accelerating Evolutionary Change} through Adaptive and Directed Mutation Editor: Saier, M.H. (La Jolla, Calif.)

Editor: Saier, M.H. (La Jolla, Calif.)
82 p., 23 fig., 4 in color, 7 tab., soft cover, 2012 CHF 39.- / EUR 33.- / USD 46.00

Prices subject to change

EUR price for Germany, USD price for USA only

ISBN 978-3-8055-9920-7

e-ISBN 978-3-8055-9921-4

Special Topic Issue:

Journal of Molecular Microbiology and

Biotechnology

Vol. 21, No. 1-2 (2011)

Included in subscription anscriptional De-Repression and Mfd artin,

ansposon-Mediated Adaptive and Directed Mutations and Their Potential Evolutionary Evolution: Novella, I.S.; Presloid, J.B.; Smith, S.D.;

Author Index

Subject Index

\section{$\rightarrow$ Please send: ___ copy/ies}

Postage and handling free with prepayment

E

- Please charge to my credit card

- $\square$ American Express $\square$ Diners

ᄂ $\square$ MasterCard $\square$ Visa

- Card No.

๑

ठ Exp. date

-

- CVV/CVC

( 3 digits in the signature field on the back of Visa and MasterCard)

$\square$ Check enclosed $\square$ Please bill me

Orders may be placed with any bookshop, subscription agency, directly with the publisher or through a Karger distributor.
Fax: +41613061234

S. Karger AG, P.O. Box, CH-4009 Basel (Switzerland)

E-Mail orders@karger.ch, www.karger.com

Name/Address: 